\title{
Recent crime legislation and the challenge for prison health care
}

\author{
Adelina Iftene LLB LLM, Allan Manson LLB LLM
}

See related editorial by Flegel and Bouchard at www.cmaj.ca/lookup/doi/10.1503/cmaj.130149

Competing interests: None declared.

This article has been peer reviewed.

Correspondence to:

Allan Manson,

mansona@queensu.ca

CMAJ 2013. DOI:10.1503 /cmaj.120222
$\mathrm{F}$ rom a health perspective, prisoners represent a special segment of the population. First, their backgrounds often include family dysfunction, low socioeconomic status, substance abuse, little education and an inordinate rate of mental health problems. Second, the prison is a totally controlled environment with its own culture that includes violence, coercion and drug use, and its own security tools such as classification, discipline and segregation. In a prison environment, security always trumps other concerns. As a result, the vulnerable can easily become more vulnerable, and the healthy can soon become unhealthy.

Much public attention has been paid recently to Bill $\mathrm{C}-10,{ }^{1}$ the omnibus federal crime bill that will affect sentencing, parole, corrections and pardons. Without substantial expansion of the prison system, this legislation combined with other recent criminal law will increase prison populations, exacerbating the current overcrowding in most institutions. This article provides an overview of the current health status of the Canadian prison population, recent legislation and the impact of overcrowding, with a predominant focus on the federal system.

Canada has 2 correctional systems. At the federal level, all prisoners serving sentences of 2 years or more are confined in penitentiaries operated by the Correctional Service of Canada. As of 2010, there were 13531 prisoners in 57 federal institutions. ${ }^{2}$ In provinces and territories, prisons and jails house prisoners serving sentences of less than 2 years and people detained

\section{- KeY POINTS}

- Bill C-10 and related legislation provides for more minimum sentences and reduced possibilities for conditional release, which will result in more people behind bars for longer periods.

- Without more resources, overcrowding will result.

- Overcrowding is already a pressing issue in most prisons in Canada and abroad.

- Studies have shown that the effects of overcrowding include increased mental health disorders and physical problems. on remand pending trial. Each jurisdiction has its own statutory framework governing its respective correctional system.

\section{Health care in corrections}

The Corrections and Conditional Release Act stipulates that all federal prisoners shall receive "essential health care" in conformity with "professionally accepted standards." ${ }^{3}$ Conventions ratified by Canada, such as the International Covenant on Economic, Social and Cultural Rights, and the United Nations Standard Minimum Rules for the Treatment of Prisoners, affirm that prisoners have the right to the highest attainable level of health care. Together, these legal instruments support the view that the standard of health care for prisoners should be comparable to that available to citizens in the community.

The Correctional Service of Canada operates health care facilities in every institution, and each region has a regional hospital as well as a regional treatment centre. At the institutional level, the health care facility offers primary nursing care (often 24-hour), supplemented by visits from primary care physicians, 2 or more times weekly, and from specialists. Prisoners are transferred to community hospitals for major surgeries and specialized treatment. The regional hospital is intended to provide postoperative care as well as some acute and chronic care (e.g., dialysis), but its use depends on physical capacity, resources and location. Prisoners with mental health issues may be sent to an inpatient regional treatment centre or transferred to provincial mental health centres; however, most of these prisoners, especially those with nonacute symptoms, remain in their own institutions.

Only rudimentary data are available about the cost of health care in federal penitentiaries; recently, these data have been included in overall custody budgets. However, in 2008, \$108 253332 was spent on physical health care (including health policy, quality improvement and accreditation, clinical services and public health),${ }^{4}$ which 
represented less than $10 \%$ of the custody budget. A 2011 audit disclosed that \$25 million was allocated to regional treatment centres for delivery of mental health care. ${ }^{5}$

\section{Health of prisoners}

Prisoners use health services more than the general population, with an average of 20 nursing visits per prisoner per year. ${ }^{6}$ Many have led lives of abuse and did not benefit from appropriate health care before incarceration. In custody, they are faced with the stressors of imprisonment, such as cultural shock, fear of victimization and violence, isolation, shame, anxiety, depression, contagious diseases and susceptibility to drug use. ${ }^{7}$ As a result, it has been suggested that the biological age of a prisoner is $10-15$ years older than his or her chronological age. ${ }^{6}$ The prison population has far more acute and chronic conditions than the general population, with an average of 3 diseases per inmate over the age of 50 years. ${ }^{6}$ Studies in both Canada and the United States show that, compared with older populations in the community (defined by age $>65 \mathrm{yr}$ ) ${ }^{8}$ older populations in prisons (defined by age $>50 \mathrm{yr}$ ) have larger percentages of people with chronic diseases, such as hypertension $(37 \%$ among prisoners v. $1 \%-2 \%$ among the general population), heart disease $(30 \%$ v. $10 \%-20 \%)$ and hearing impairments (32\% v. $16 \%) .{ }^{6.8}$

In addition, a 2009/10 report from the Office of the Correctional Investigator indicated the rate of HIV infection was 7-10 times higher in prisons compared with the community, and the rate of infection with hepatitis $\mathrm{C}$ was reported to be 30-40 times higher than in the community (affecting about $30 \%$ of prisoners). ${ }^{9}$

The same document reported a $20 \%$ vacancy in mental health staff positions in prisons, and stated that $37 \%$ of male prisoners and $50 \%$ of female prisoners had symptoms of mental health problems that needed additional assessment. ${ }^{10}$ In a study of 1300 incoming prisoners, $38.4 \%$ had problems pertaining to mental health. ${ }^{10}$ Of these, $20 \%$ were suicidal, $29.9 \%$ had obsessive-compulsive disorder, $36.9 \%$ had depressive symptoms, $31.1 \%$ had anxiety, $30.6 \%$ had paranoid ideation and $51 \%$ had a form of psychosis. ${ }^{10} \mathrm{~A}$ US study reported that depression was 50 times more common in incarcerated people than in the community. ${ }^{11}$

\section{Effect of Bill C-10 and related legislation}

Previous legislation related to the federal "toughon-crime" agenda has reduced the usual 2-for-1 credit for presentence custody (i.e., 2 days' credit deducted from the sentence for each day served in presentence custody) to a new norm of a 1 -for- 1 credit, with a potential in some cases for a 1.5 -for- 1 credit. It has also changed the murder-sentencing regime so that a person convicted of murder is no longer able to seek a reduction of the parole ineligibility period after serving 15 years of a life sentence. Bill C-10, or the Safe Streets and Communities Act, ${ }^{1}$ an omnibus crime bill incorporating amendments to multiple laws, contains a number of provisions that may lead to larger prison populations. For example, eligibility for conditional sentences has been reduced for an array of offences, and amendments to the Youth Criminal Justice Act make it easier for prosecutors to seek both custodial and adult sentences.

In addition, many mandatory minimum sentences have increased. For example, trafficking in specified circumstances now carries a mandatory minimum of $1-2$ years.

At the parole stage, the National Parole Board will no longer be guided by the "least restrictive principle" (i.e., the use of the least intrusive disposition required to achieve public protection), and prisoners who are denied day or full parole will have to wait longer before they can reapply.

In summary, Bill C-10 will likely have a dramatic impact on the size of prison populations and the stability of prison environments. We can expect an aggravation of the current state of overcrowding, an increase in correctional costs, more young people in custody, and prisoners spending longer periods in prison and being more isolated. Of course, new capacity demands can be addressed by building more prison cells. The federal Office of the Correctional Investigator has predicted that penitentiaries will need to accommodate 3400 more prisoners by $2013 .{ }^{12}$ Ontario expects it will need a new prison for 1000 prisoners at a cost of $\$ 900$ million, and Quebec is anticipating spending up to $\$ 600$ million on new cells..$^{13}$ In an era of governmental budgetary restraint, is it likely that these allocations will be made? Regardless of new capital expenditures, it is reasonable to assume that increasing demands on correctional systems will affect allocations for internal programs, including health care.

\section{Overcrowding and health risks}

While Canada is moving to increase its prison populations, other jurisdictions are responding to overcrowding by decarcerating people. More than 15 years ago, studies in the US began showing the negative impact of overcrowding. ${ }^{14} \mathrm{In}$ 
Europe, the Committee of Ministers has recommended reductionist penal policies. ${ }^{15}$ The European Committee for the Prevention of Torture and Inhuman or Degrading Treatment or Punishment has reported that overcrowding is linked to inadequate sanitary facilities and insufficient activities for prisoners, and may represent a violation of human rights. ${ }^{16}$ Some cases brought to the European Court of Human Rights have shown that overcrowding can lead to inadequate medical treatment. ${ }^{17}$ Overcrowding is related to feelings of helplessness, interference in personal behaviour, stress, enhanced medical demand and higher average blood pressure. ${ }^{18}$

In Canada, the 2009/10 report of the Office of the Correctional Investigator stated that overcrowding had increased by $50 \%$ in the previous few years, resulting in many prisoners already sleeping in bunk beds or on the floor. ${ }^{19}$ The investigator suggested that double-bunking (i.e., housing 2 prisoners in a space intended for 1), whether for the short or long term, is never a solution.

In the 2010/11 report, the investigator reported that about $13 \%$ of the population was doublebunked; he expected this would increase to $30 \%$ in the next 3 years. ${ }^{12}$ The situation in the Prairies, where $20 \%$ of the prison population is doublebunked, is the most acute, followed by Ontario with $14 \%$. The correctional investigator reported that overcrowding leads not only to health issues, such as infectious diseases, but also to managerial problems. In 2010/11 there were 19769 security incidents, of which 1258 required the use of force to manage. There was at least 1 homicide attributable to improper cell assignment. ${ }^{12}$

Overcrowding has long been a problem for provincial prisons. Between 2000/01 and 2008/09, the population of these institutions increased by $9 \% .^{2}$ The number of remand prisoners awaiting trial increased from an average of $26 \%$ of prisoners in 1990 to $57 \%$ in $2009 .{ }^{2}$ A 2002 report from the John Howard Society of Ontario mentioned troubling conditions in the Toronto West Detention Centre, where 3 people were living in a cell designed for 1 , which meant that 1 person was sleeping on the floor next to the toilet..$^{20}$ The Ombudsman of Ontario concluded that these conditions did not meet the UN Standard Minimum Rules for the Treatment of Prisoners. ${ }^{20}$

Dramatic increases in an already overcrowded prison population can have a serious impact on health care services. The prison population already has higher rates of infectious diseases than the community population. ${ }^{9}$ The Canadian HIV/AIDS Legal Network has indicated that 30 to 40 prisoners might use the same syringe to inject drugs. ${ }^{21}$ Yet, recommendations from the correctional investigator to provide a needle exchange program to help prevent the transmission of HIV and hepatitis have not been heeded. ${ }^{9}$ Given that needle exchange programs are available outside the prison, the network stated that the "highest attainable standard of health" in prisons was not being reached..$^{22}$ It is reasonable to conclude that an increase in the number of prisoners will exacerbate these problems.

In addition to the relation between drug use and infectious diseases, studies have shown a cooccurrence of substance abuse and mental illnesses. Of prisoners serving sentences of 2 years or more, $80 \%$ use drugs in prison and most present some symptoms of mental illness. ${ }^{23}$

The potential restriction of family visits as a result of Bill C-10 may have devastating effects on the mental and emotional status of prisoners. A US study of female prisoners showed that family visits were crucial for maintaining the well-being, self-esteem and motivation of prisoners, while decreasing feelings of guilt, anxiety and depression. ${ }^{24}$ Prisoners with family ties were more likely to engage in programs and to avoid hopelessness. ${ }^{24} \mathrm{An}$ increased number of prisoners run the risk of overwhelming an already overburdened system unless more is invested in mental health care.

As well as health care, proper institutional programming is needed to motivate inmates, stabilize their mental status, give them a purpose and enhance their physical condition. As numbers increase, fewer prisons can offer proper programming to most of their prisoners. ${ }^{24-26}$ The Office of the Correctional Investigator report, which linked overcrowding to an increase in institutional violence, also anticipated with overcrowding greater fear of victimization and decreased safety, especially for physically and mentally ill prisoners, and decreased access to correctional programs and health care. ${ }^{10}$

\section{Conclusion}

By incarcerating more people, exposing them to an increased potential for violence, and keeping them in prison longer, the system will further foster an environment of mental, emotional and physical degradation.

Physicians aspire to the oath of Athens established by the international community more than 30 years ago:

We, the health professionals who are working in prison settings, meeting in Athens on September 10, 1979, hereby pledge, in keeping with the spirit of the Oath of Hippocrates, that we shall endeavour to provide the best possible health care for those who are incarcerated in prisons for whatever reasons, without prejudice and within our respective professional ethics. ${ }^{27}$ 
Prison systems need to provide a context amenable to achieving this goal.

From both an ethical and public safety perspective, one needs to consider a simple fact. In 2008, 240491 people entered Canadian prisons as sentenced or remand prisoners, and more than $99.9 \%$ of them would at some point be released back into the community. ${ }^{28}$ The intrinsic difficulties of reintegration after a period of incarceration should not be compounded by physical and mental health issues. This is the challenge for Canadian prison systems facing increased populations in the age of overcrowding. The challenge for physicians and other health care professionals is to maintain standards of care. At the same time, they must monitor changes produced by increased overcrowding and be prepared to participate in the public discourse when these changes affect their ability to deliver proper care.

\section{References}

1. Bill C-10, An act to enact the Justice for Victims of Terrorism Act and to amend the State Immunity Act, the Criminal Code, the Controlled Drugs and Substances Act, the Corrections and Conditional Release Act, the Youth Criminal Justice Act, the Immigration and Refugee Protection Act and other acts. 1st Sess., 41st Parl, 2012, (Royal Assent Statutes of Canada: 2012, c. 1). Available: www.parl.gc.ca/LegisInfo/BillDetails.aspx?Mode $=1 \&$ billId $=5120829 \&$ Language $=\mathrm{E}$ (accessed 2012 Aug. 28).

2. Corrections and conditional release statistical overview, 2010. Ottawa (ON): Public Safety Canada; 2010. Available: www .publicsafety.gc.ca/res/cor/rep/2010-ccrso-eng.aspx (accessed 2012 Jan. 30).

3. Corrections and Conditional Release Act, SC 1992, c20, s. 86.

4. Audit of physical health care delivery to inmates, internal audit branch. Ottawa (ON): Correctional Service Canada; 2008. App C, p. 35. Available: www.csc-scc.gc.ca/text/pa/adt-phc-378-1-236 /adt-phc-378-1-236-eng.pdf (accessed 2012 Jan. 30).

5. Audit of regional treatment centres and the regional psychiatric centre. Ottawa (ON): Correctional Service Canada; 2011. p. 8. Available: www.csc-scc.gc.ca/text/pa/adt-rtc-rpc-378-1-252/adt-rtc -rpc-378-1-252-eng.shtml (accessed 2012 Jan. 30).

6. Aday RH. Aging prisoners. London (UK): Praege; 2003. p. 17-20.

7. Delgado M, Delgado D-H. Health and health care in the nation's prisons. Lanham (MD): Rowman \& Littlefield Publishers; 2009. p. $87-123$.

8. Ham R, Sloane P, Warshaw G, et al. Primary care geriatrics. Philadelphia (PA): Mosby Elsevier; 2007. p. 425-600.

9. Annual report 2009-2010. Ottawa (ON): Office of the Correctional Investigator; 2010. p. 22-4. Available: www.oci-bec.gc.ca /rpt/index-eng.aspx (accessed 2012 Jan. 30).

10. Annual report 2010-2011. Ottawa (ON): Office of the Correctional Investigator; 2011. p. 11. Available: www.oci-bec.gc.ca /rpt/index-eng.aspx (accessed 2012 Jan. 30).

11. Williams B, Abraldes R. Growing older: challenges of prison and reentry for the aging population. In: Gerifinger R, editor. Public health behind bars: from prisons to communities. London (UK): Springer; 2007. p. 61

12. Annual report 2010-2011. Ottawa (ON): Office of the Correctional Investigator; 2011. p. 31-8. Available: www.oci-bec.gc.ca /rpt/index-eng.aspx (accessed 2012 Jan. 30).

13. Wilson T. Why crime bill should be concern for business. The Globe and Mail [Toronto (ON)]: 2012 Mar. 13. Available: www.theglobeandmail.com/report-on-business/small-business/sb -growth/day-to-day/why-crime-bill-should-be-concern-for-business /article535787/ (accessed 2012 Aug. 20).

14. Ornduff JS. Releasing the elderly inmate: a solution to prison overcrowding. Elder Law Journal 1996;4: 173

15. Recommendation R. (99) 22 of the Committee of Ministers concerning prison overcrowding and prison population inflation, 1999, (Adopted by the Committee of Ministers on 30 September 1999 at the 681st meeting of the Ministers' Deputies). Available: www.legislationline.org/documents/action/popup /id/8040 (accessed 2012 Jan. 30).
16. 2nd General Report on the CPT's activities covering the period 1 January to 31 December 1991. Council of Europe; 1992. Available: www.cpt.coe.int/en/annual/rep-02.htm (accessed 2012 Jan. 30)

17. Kudla v. Poland (2000) in: European Court of Human Rights. HUDOC database. Available: www.echr.coe.int/ECHR/EN /Header/Case-Law/Decisions+and+judgments/HUDOC+database/ (accessed 2012 Oct. 29).

18. Zyl Smit D, Snacken S. Principles of European prison law and policy. Oxford University Press; 2011. p. 131.

19. Annual report 2009-2010. Ottawa (ON): Office of the Correctional Investigator; 2010. p. 37-8. Available: www.oci-bec.gc.ca /rpt/index-eng.aspx (accessed 2012 Jan. 30).

20. John Howard Society of Ontario. Conditions in Ontario provincial prisons: a troubling picture. Fact sheet \#18. Kingston (ON): The Society; 2002.

21. Chu SHK, Peddle K, Elliott R. Under the skin: a people's case for prison needle and syringe programs. Toronto $(\mathrm{ON})$ : Canadian HIV/AIDS Legal Network; 2010. p. 29-32. Available: www.aidslaw.ca/EN/aids2010/documents/AIDS10_SC-UTS.pdf (accessed 2012 Jan. 30)

22. Chu S, Elliott R. Clean switch: the case for prison needle and syringe programs in Canada. Toronto (ON): Canadian HIV/AIDS Legal Network; 2009.

23. Mental health and drug and alcohol addiction in the federal correctional system. Report of the Standing Committee on Public Safety and National Security. 3rd Sess, 40th Parl, 2010, p. 13.

24. Aday RH, Krabill JJ. Women aging in prison: a neglected population in the correctional system. Boulder (CO): Lynne Rienner Publishers, 2011.

25. Aday RH. Aging prisoners. London (UK): Praege; 2003. p. 144.

26. Cox JF, Lawrence JE. Planning services for elderly inmates with mental illness. Corrections Today June 2010. Available: www.aca .org/fileupload/177/ahaidar/1_Cox_Lawrence.pdf (accessed 2012 Aug. 28).

27. International Council of Prison Medical Services. Oath of Athens. Prison Health Care Practitioners; 1979.

28. Adult Correctional Services in Canada, 2008/2009. 85-002-x, Juristat, Fall 2012. Available: www.statcan.gc.ca/pub/85-002-x /2010003/article/11353-eng.htm (accessed 2012 Oct. 26).

Affiliation: From the Faculty of Law, Queen's University, Kingston, Ont.

Contributors: Both authors drafted and revised the article for important intellectual content, and gave final approval of the version submitted for publication.

Acknowledgement: The authors thank Anthony Doob for his thoughtful comments on an early draft of this article.

\section{Call for papers: CMAJ Holiday Reading}

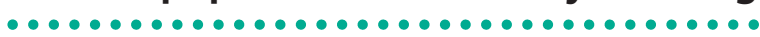

'Twas months before the holidays and all through CMAJ house not a submission was stirring, making editors grouse. "Holiday Reading time is nigh!" they cried in despair, in hopes that your papers soon would be there.

\section{Submit your evidence-based} research on quirky topics, brilliant missives or holiday-themed visuals at http://mc.manuscriptcentral.com /cmaj. Submissions should be no longer than 1200 words. For information contact kelly.clarke@cma.ca

Deadline: October 1, 2013

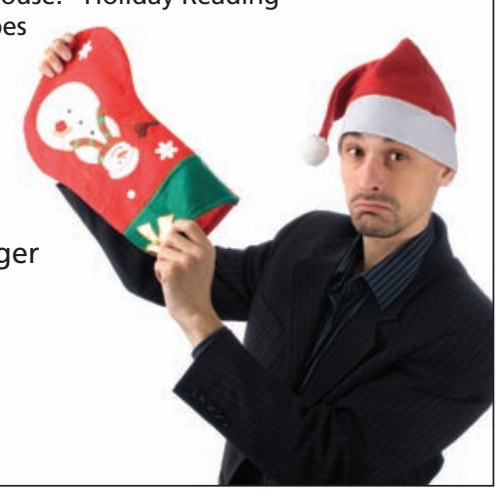

